\title{
Survival in Operated Early and Local Advanced-Stage (IA-IIIA) Non-Small Cell Lung Cancer
}

\author{
Mahsuk Taylan ${ }^{1}$, Sibel Arinc ${ }^{2}$, Aysun Kosif Misirlioglu³, Sinan Bodur 2 , Selahattin Oztas ${ }^{2}$, \\ Mevlut Karatas ${ }^{4}$ İlim Irmak ${ }^{2}$, Huseyin Arpag ${ }^{5}$, Armagan Hazar ${ }^{2}$
}

\section{ABSTRACT}

Objective: The early and local advanced stages (IA-IIIA) of non-small cell lung cancer (NSCLC) warrant the curative treatment approach of surgery. However, despite the surgical approach, survival depends on a number of factors. The aim of the study was to examine the factors that affect survival in operated NSCLC patients with these stages.

Methods: A cohort of 231 operated patients with IA, IB, IIA, IIB, and IIIA stages of NSCLC were analyzed. The effects of age, sex, comorbidity, performance status, histopathology of the tumor, T stage, N stage, pleural invasion, surgical resection type and postoperative resection margin invasion on the survival of the patients were examined with KaplanMeier and Cox Regression analyses.

Results: Advanced age ( $\mathrm{OR}=1.042$ for every passing year, $\mathrm{Cl}=1.020-1.064)$, adenocarcinoma histopathology $(\mathrm{OR}=1.676$ $\mathrm{Cl}=1.178-2.384), \mathrm{N} 2$ invasion $(\mathrm{OR}=2.389 \mathrm{Cl}=1.46-4.239)$, pleural invasion $(\mathrm{OR}=2.403 \mathrm{Cl}=1.569-3.678)$, resection margin invasion $(\mathrm{OR}=2.401, \mathrm{Cl}=1.141-5.048)$ and pneumonectomy as the type of surgical operation $(\mathrm{OR}=2.313, \mathrm{Cl}=1.467$ 3.647) were found to be independent prognostic factors of mortality.

Conclusion: Follow-up of the NSCLC cases with advanced age, an adenocarcinoma type, visceral pleural invasion, N2lymph node invasion, a history of pneumonectomy, and a resection margin invasion should be undertaken more attentively during planning of surgical operation and postoperative period. J Clin Exp Invest 2016; 7 (2): 125 -133

Key words: Survival, mortality, performance score, operated, non-small cell lung cancer

\section{Opere Edilmiş Erken ve Lokal İlerlemiş Evre (IA-IIIA) Küçük Hücreli Olmayan Akciğer Kanserinde Sağkalım}

\section{ÖZET}

Amaç: Erken ve Lokal ileri evre (IA-IIIA) küçük hücreli dışı akciğer kanserinin (KHDAK) kesin tedavisi cerrahidir. Ancak cerrahi tedaviye rağmen sağ kalımı etkileyen bir çok faktör mevcuttur. Bu çalışmanın amacı opere KHDAK hastalarda sağ kalımı etkileyen faktörleri saptamaktır.

Yöntemler: Opere edilen evre IA, IB, IIA, IIB ve IIIA toplam 231 KHDAK hastanın verisi analiz edildi. Yaş, cinsiyet, ek hastalık, performans skoru, tümör histopatolojisi, T ve N durumu, Plevral invazyon, cerrahi rezeksiyon tipi ve postoperatif cerrahi sınırda tümör invazyonunun sağ kalım üzerindeki etkileri Kaplan-Meier ve Cox Regresyon analiziyle araştırıldı.

Bulgular: İleri yaş (Artan her yaş için $\mathrm{OR}=1.042, \mathrm{Cl}=1.020-1.064)$, adenokarsinom histopatolojisi $(\mathrm{OR}=1.676 \mathrm{Cl}=1.178$ 2.384), $\mathrm{N} 2$ invazyonu ( $\mathrm{OR}=2.389 \mathrm{Cl}=1.46-4.239)$, plevral invazyon $(\mathrm{OR}=2.403 \mathrm{Cl}=1.569-3.678)$, rezeksiyon sınırında tümör varlığı $(\mathrm{OR}=2.401, \mathrm{Cl}=1.141-5.048)$ ve operasyon tipi olarak pnömonektomi $(\mathrm{OR}=2.313, \mathrm{Cl}=1.467-3.647)$ mortalite için bağımsız prediktörler olarak saptandı.

Sonuç: İleri yaştaki, adenokanser tipine sahip, viseral plevra invazyonu veya N2 tutulumu olan, pnömomonektomi operasyonu geçiren ve cerrahi sınırda tümör pozitifliği görülen opere erken ve lokal ileri evre KHDAK tanılı hastaların perioperatif ve postoperatif dönemdeki takipleri dikkatli planlanmalıdır.

Anahtar kelimeler: sağkalım, mortalite, performans skoru, opere edilmiş, küçük hücreli olmayan akciğer kanseri

${ }^{1}$ Dicle University Faculty of Medicine, Department of Chest Disease, 21020 Diyarbakir, Turkey

${ }^{2}$ Sureyyapasa Training and Research Hospital, Department of Chest Disease, 34854 istanbul, Turkey

${ }^{3}$ Sureyyapasa Training and Research Hospital, Department of Chest Surgery, 34854 istanbul, Turkey

${ }^{4}$ Recep Tayyip Erdogan University Faculty of Medicine, Department of Chest Disease, 5300 Rize, Turkey

${ }^{5}$ Sutcu Imam University Faculty of Medicine, Department of Chest Disease, 46100 Kahramanmaras, Turkey

Correspondence: Mahsuk Taylan,

Dicle University Faculty of Medicine, Department of Chest Disease, 21020 Diyarbakir, Turkey Email: mahsuktaylan@gmail.com Received: 16.02.2016, Accepted: 09.03.2016

Copyright (C) JCEI / Journal of Clinical and Experimental Investigations 2016, All rights reserved 


\section{INTRODUCTION}

Lung cancer is the type of cancer that represents the highest level of mortality in the world and is mostly observed in the non-small cell lung cancer (NSCLC) histological subtype. Surgery is still the most effective treatment modality in early- and local advanced-stage (IA-IIIA) NSCLC and has been shown to contribute to survival [1].

TNM staging is one of the important decision criterions for surgical operation, however survival has been reported to be affected by factors other than staging parameters including demographic data such as age, sex and performance score [2]. It has also been reported to be affected by factors outside the scope of staging components such as the histological type and differentiation grade of the tumor as well as type of surgical operation [3].

Most survival studies do not include all stages, since the stage itself effects survival. Instead, they utilize a patient population of a single or sub stage. There are a limited number of long-term survival studies that cover all stages and examine a number of factors $[4$, 5]. To work with all risk factors including stage components separately, may be more helpful rather than working with only a stage or sub stage population due to give the possibility to measure the impact of independent predictors comprehensively.

In the present study, we aimed to examine the correlation between preoperative (demographic data, histopathology of the tumor, stage components), perioperative (type of surgical operation) and postoperative findings (residual tumor in surgical border) and survival in operated patients who were diagnosed all with early- and local advanced-stage NSCLC.

\section{METHODS}

\section{Patients}

The data belonging to 298 consecutive patients who had been diagnosed with NSCLC and undergone resection upon the identification of early- or local advanced-stage (stages IA-IIIA) were retrospectively reviewed from the hospital records. Ethical approval was obtained.

Data on age, sex, date of diagnosis, and date of death were noted. The dates of death were accessed through the Central National Database. The patients' smoking status at the time of diagnosis, Eastern Cooperative Oncology Group Performance Status Score
(ECOG PS) [6], radiological and bronchoscopic localization and histopathology of the tumor, pathological (TNM) stage, type of surgical operation (lobectomy, bilobectomy, and pneumonectomy), pleural invasion, vascular invasion, and resection margin invasion were recorded.

TNM staging was based on The 2009 Seventh Edition of the TNM Classification of Malignant Tumors revision of the International Association for the Study of Lung Cancer (IASLC) [7].

\section{Exclusion Criteria}

Patients who had been identified to have early- or local advanced-stage (IA-IIIA) NSCLC, yet could not be operated on for any reason; who could not be reached for the identification of health status; and who were unable to be followed-up with (67 cases in total) were excluded from the study. The study was implemented with 231 patients, as 67 patients were lost due to inability to follow-up.

\section{Statistical Analysis}

Statistical analyses were carried out with the use of SPSS Version 21. The effects of sex, ECOG performance score, comorbidity, tumor histotype, T stage, $\mathrm{N}$ stage, pleural invasion, vascular invasion and surgical margin positivity, and type of surgical resection on survival were examined in the log rank test. Survival rates were calculated by employing the Kaplan-Meier survival analysis.

In the multi-variant analysis, the independent factors in prognostic survival were examined with Cox regression analysis with the backward selection method by utilizing the potential factors identified in previous analyses. In the scope of Kaplan-Meier analysis, those parameters which were clinically significant for the model were selected from amongst the interrelated parameters that indicated a similar effect. Assumptions concerning model fitness and proportionality of seasonal risk were assessed with residual (Schoenfeld and Martingale) analyses. Situations where type- 1 error level was below 5\% were considered statistically significant.

\section{RESULTS}

\section{Demographical and clinical characteristics of patients}

A total of 231 patients composed of a $93.5 \%$ male population with a mean age of $56.2 \pm 8.5$ years was studied. 
The smoker proportion was $94.4 \%$ with consumption of $45.6 \pm 25.5$ package-years. There were no patients with ECOG PS above ' 2 ' at the time of the diagnosis (Table 1 ). The rate of co-morbidity was $41.6 \%$, including lung diseases $(29.4 \%)$ such as COPD, cardiovascular diseases $(26 \%)$ such as hypertension and ischemic heart disease, and other systemic diseases (35\%). The rate of two or more co-morbid diseases was $5 \%$.

The right lung was the most common tumor localization (54\%), with the right upper lobe predominating $(35.9 \%)$ (Table1). The tumor histopathological sub-types encountered were $56.2 \%$ squamous cell carcinoma and $43.5 \%$ adenocarcinoma.T2 stage was most common (58.4\%) and T3 was less (14.3\%). The majority of the patients did not have LN metastasis (78.7\%). Stage IB was found as most common pathological stage (38.1\%) followed by stage IIA (19\%) (Table 1). Lobectomy was the most commonly performed surgical procedure $(57.1 \%)$ followed by pneumonectomy $(36.3 \%)$. The proportion of pleural invasion was $17.3 \%$, vascular invasion $21.3 \%$ and surgical margin invasion was $4.3 \%$ of the total number of patients (Table1).

\section{Results of survival analysis}

After a follow-up of at least five years, the number of living patients was identified as $92(39.8 \%)$, and the number of deceased patients as $139(60.2 \%)$.

The Kaplan-Meier analysis indicated the factors affecting survival to be, ECOG PS ( $\mathrm{p}=0.018)$, tumor histopathology $(\mathrm{p}=0.033)$, pleural invasion $(\mathrm{p}<0.001)$, $\mathrm{N}$ stage $(\mathrm{p}=0.044)$, T Stage $(\mathrm{p}=0.003)$, and type of surgical resection $(\mathrm{p}=0.018)$.

Mean survival time was found to be reduced in patients with ECOG PS 2 (30.3 months) compared to patients with PS '0' (85.4 months). Mean survival time was less in patients with adenocarcinoma (53.7 months) compared to those with squamous CA (68.7 months). Patients with visceral pleural invasion had a shorter survival time (40.3 months) than patients with no invasion (67.1 months). Patients with N2-invasion had the shortest survival (34.5 months) compared with the N0 group (65.6 months). Stage IA patients were found to exhibit the longest survival time (71.6 months). Survival time was gradually reduced in proportion with advancing stage and was identified to be
29.3 months in stage IIIA patients (Table 1) (Figure $1-6)$.

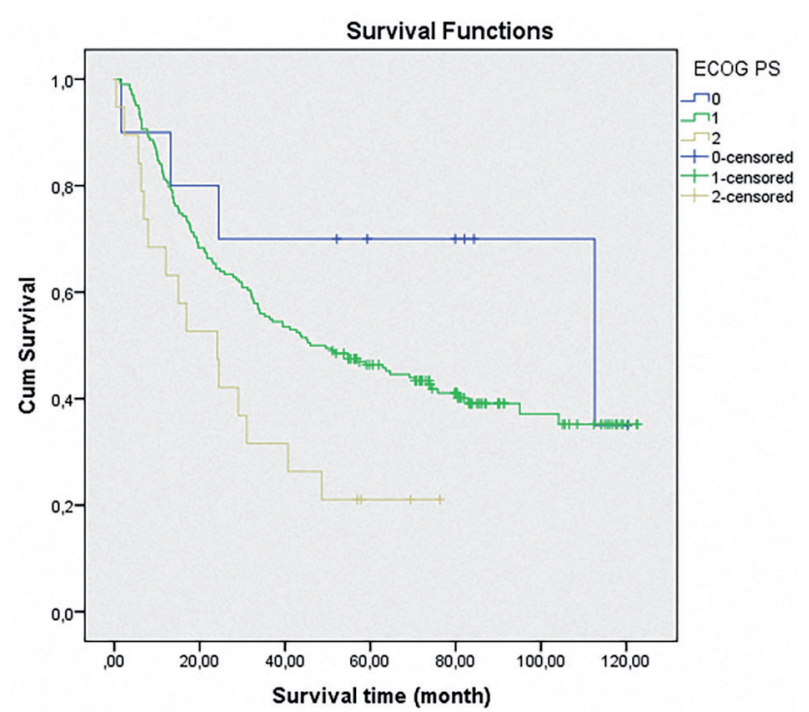

Figure 1. Survival distributions by ECOG Performance score (PS)

The Cox Regression analysis revealed that every advancing age increased the risk of mortality by 1.042 (95\% CI: $1.020-1.064)$. It was identified that the presence of the histopathology of adenocarcinoma increased the risk of mortality by 1.505 when compared to squamous cell carcinoma (95\% CI: 0.876-2.583). N2-lymph node invasion increased the risk of mortality by 2.389 (95\% CI: 1.46-4.239) when compared to N0. The presence of pleural invasion increased the mortality by 2.403 (95\% CI: 1.569-3.678) when compared to its absence. In addition, resection margin positivity increased the mortality by 2.401 (95\% CI: 1.141-5.048) when compared to non-invaded margin group. Furthermore, left lobectomy, right bilobectomy, right pneumonectomy, and left pneumonectomy resections were found to indicate, 1.598 (95\% CI: $0.826-3.094), 1.568$ (95\% CI: $0.873-2.817)$, and 2.313 (95\% CI: $1.467-3.647)$ times higher risk of mortality when compared to right lobectomy, respectively. The contribution of ECOG PS to survival was found to be close to the margin of significance $(\mathrm{p}=0.061)$. ECOG PS 1 and 2 values were identified to be associated with a higher risk of mortality when compared to the ECOG PS ‘0'score group respectively (Table 2). 
Table 1. Patient characteristics and results of survival (Kaplan-Meier) analysis

\begin{tabular}{|c|c|c|c|c|c|c|c|}
\hline & & n (\%) & $\begin{array}{l}\text { Survival time } \\
\text { (month) }\end{array}$ & SE & $\begin{array}{l}\mathrm{Cl} 95 \% \\
\text { Lower B L }\end{array}$ & oper B & P (logRank) \\
\hline \multirow{2}{*}{ Gender } & Female & $15(6.5)$ & 67.25 & 11.97 & 43.79 & 90.71 & \multirow{2}{*}{0.672} \\
\hline & Male & $216(93.5)$ & 62.14 & 3.42 & 55.42 & 68.85 & \\
\hline \multirow{2}{*}{ Smoking status } & No smoker & $13(5.6)$ & 62.45 & 11.90 & 39.13 & 85.77 & \multirow{2}{*}{0.971} \\
\hline & Smoker & $218(94.4)$ & 60.11 & 3.68 & 52.89 & 67.32 & \\
\hline \multirow{2}{*}{ Comorbidity } & No & $135(58.4)$ & 61.04 & 5.40 & 50.45 & 71.63 & \multirow{2}{*}{0.949} \\
\hline & Yes & 96 (41.6) & 60.41 & 6.08 & 48.50 & 72.32 & \\
\hline \multirow{3}{*}{ ECOG PS } & 0 & $10(4.3)$ & 85.42 & 15.19 & 55.66 & 115.18 & \multirow{3}{*}{0.018} \\
\hline & 1 & $202(87.5)$ & 63.67 & 3.51 & 56.79 & 70.56 & \\
\hline & 2 & $19(8.2)$ & 30.36 & 6.15 & 18.30 & 42.41 & \\
\hline \multirow{2}{*}{ Histopathology } & Squamouse cell $\mathrm{Ca}$ & $131(56.2)$ & 68.78 & 4.40 & 60.16 & 77.40 & \multirow{2}{*}{0.033} \\
\hline & adeno $\mathrm{Ca}$ & $100(43.8)$ & 53.74 & 4.76 & 44.42 & 63.07 & \\
\hline \multirow{2}{*}{ Vascular invasion } & No & $182(78.7)$ & 61.88 & 3.67 & 54.69 & 69.07 & \multirow{2}{*}{0.719} \\
\hline & Yes & $49(21.3)$ & 59.25 & 6.35 & 46.79 & 71.70 & \\
\hline \multirow{2}{*}{ Surgical margin } & Negative (free) & 221 (95.7) & 63.37 & 3.39 & 56.74 & 70.01 & \multirow{2}{*}{0.175} \\
\hline & Positive (invaded) & $10(4.3)$ & 33.51 & 6.78 & 20.22 & 46.79 & \\
\hline \multirow{2}{*}{ Pleural invasion } & No & $191(82.7)$ & 67.12 & 3.64 & 60.00 & 74.25 & \multirow{2}{*}{$<0.001$} \\
\hline & Yes & $40(17.3)$ & 40.35 & 6.57 & 27.47 & 53.22 & \\
\hline \multirow{6}{*}{ Radiological tumor location } & Right Upper Lobe & 83 (35.9) & 61.28 & 5.27 & 50.97 & 71.60 & \multirow{6}{*}{0.289} \\
\hline & Right Middle Lobe & $10(4.3)$ & 41.61 & 15.71 & 10.83 & 72.39 & \\
\hline & Right Lower Lobe & $32(13.8)$ & 73.29 & 8.49 & 56.66 & 89.93 & \\
\hline & Left Upper Lobe & $57(24.6)$ & 61.44 & 6.79 & 48.14 & 74.74 & \\
\hline & Left (Upper L.) Lingula & $11(4.7)$ & 69.76 & 15.05 & 40.26 & 99.26 & \\
\hline & Left Lower Lobe & $38(16.7)$ & 51.77 & 6.37 & 39.28 & 64.25 & \\
\hline \multirow{5}{*}{ T Stage } & T1a & $40(17.3)$ & 71.40 & 7.27 & 57.16 & 85.65 & \multirow{5}{*}{0.063} \\
\hline & T1b & $23(10.0)$ & 68.06 & 9.54 & 49.36 & 86.76 & \\
\hline & $\mathrm{T} 2 \mathrm{a}$ & $94(40.7)$ & 65.61 & 5.21 & 55.41 & 75.82 & \\
\hline & $\mathrm{T} 2 \mathrm{~b}$ & 41 (17.7) & 55.95 & 7.74 & 40.78 & 71.11 & \\
\hline & T3 & $33(14.3)$ & 44.68 & 8.21 & 28.59 & 60.76 & \\
\hline \multirow{3}{*}{ N Stage } & NO & $182(78.7)$ & 65.68 & 3.71 & 58.41 & 72.96 & \multirow{3}{*}{0.044} \\
\hline & N1 & 27 (11.7) & 51.74 & 8.11 & 35.85 & 67.62 & \\
\hline & N2 & $22(9.6)$ & 34.54 & 6.63 & 21.54 & 47.54 & \\
\hline \multirow{5}{*}{ P Stage } & $1 \mathrm{~A}$ & $40(17.3)$ & 71.63 & 7.64 & 56.66 & 86.60 & \multirow{5}{*}{0.003} \\
\hline & $1 B$ & $88(38.1)$ & 68.72 & 5.37 & 58.19 & 79.24 & \\
\hline & $2 A$ & $44(19.0)$ & 67.52 & 7.63 & 52.56 & 82.48 & \\
\hline & 2B & 37 (16.1) & 53.99 & 8.08 & 38.16 & 69.81 & \\
\hline & $3 A$ & $22(9.4)$ & 29.30 & 5.95 & 17.65 & 40.95 & \\
\hline & Right lobectomy & $82(35.5)$ & 70.84 & 5.456 & 60.152 & 81.538 & \\
\hline & Left lobectomy & $50(21.6)$ & 72.14 & 6.961 & 58.496 & 85.785 & \\
\hline Types of Lung Surgery & Right bilobectomy & $20(8.6)$ & 56.65 & 11.508 & 34.103 & 79.215 & 0.018 \\
\hline & Right pneumonectomy & 23 (9.9) & 47.80 & 8.954 & 30.251 & 65.349 & \\
\hline & Left pneumonectomy & $56(24.4)$ & 48.43 & 5.971 & 36.73 & 60.135 & \\
\hline
\end{tabular}


Table 2. Predictors of mortality with Cox's proportional hazards regression model

\begin{tabular}{|c|c|c|c|}
\hline Risk Factor & & HR (95\% Cl) & $\mathbf{p}$ \\
\hline Age & & $1.042(1.020-1.064)$ & $<0.001$ \\
\hline \multirow[t]{4}{*}{ ECOG PS } & & & 0.061 \\
\hline & $\mathrm{ECOG} P S=0$ & 1.000 & \\
\hline & ECOG PS=1 & $0.931(0.333-2.608)$ & 0.892 \\
\hline & ECOG PS=2 & $1.832(0.584-5.745$ & 0.299 \\
\hline \multirow[t]{3}{*}{ Histopathology } & & & 0.016 \\
\hline & Squamous Ca & 1.000 & \\
\hline & Adeno Ca & $1.676(1.178-2.384)$ & 0.004 \\
\hline \multirow[t]{4}{*}{ N stage } & & & 0.006 \\
\hline & NO & 1.000 & \\
\hline & N1 & $1.505(0.876-2.583)$ & 0.138 \\
\hline & N2 & $2.389(1.46-4.239)$ & 0.030 \\
\hline \multirow[t]{2}{*}{ Pleural invasion } & no & 1.000 & \\
\hline & yes & 2.403 (1.569-3.678) & $<0.001$ \\
\hline \multirow[t]{2}{*}{ Surgical margin } & Negative (free) & 1.000 & \\
\hline & Positive (invaded) & 2.401 (1.141-5.048) & 0.021 \\
\hline \multirow[t]{6}{*}{ Types of Surgery } & & & 0.004 \\
\hline & R. Lobectomy & 1.000 & \\
\hline & L. Lobectomy & $1.070(0.646-1.772)$ & 0.792 \\
\hline & R. Bilobectomy & $1.598(0.826-3.094)$ & 0.164 \\
\hline & R. Pneumonectomy & $1.568(0.873-2.817)$ & 0.132 \\
\hline & L. Pneumonectomy & $2.313(1.467-3.647)$ & $<001$ \\
\hline
\end{tabular}

HR: Hazard ratio, R: Right, L: Left

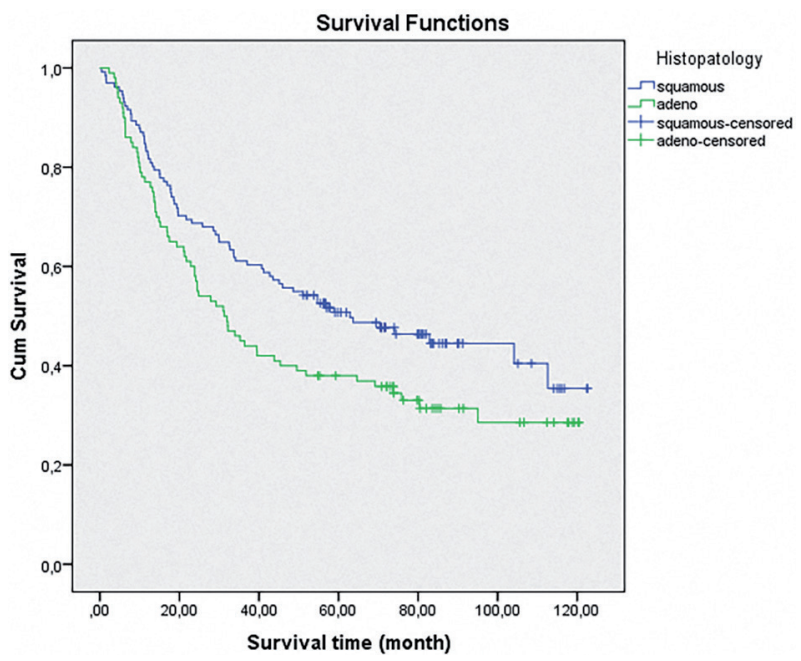

Figure 2. Survival distributions by tumor histopathology

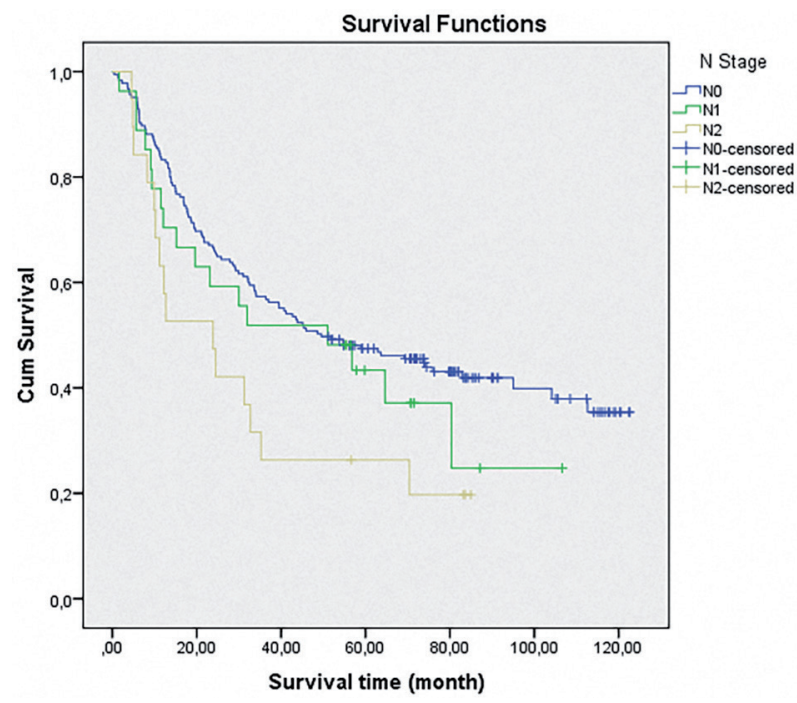

Figure 3. Survival distributions by $\mathrm{N}$ stages 


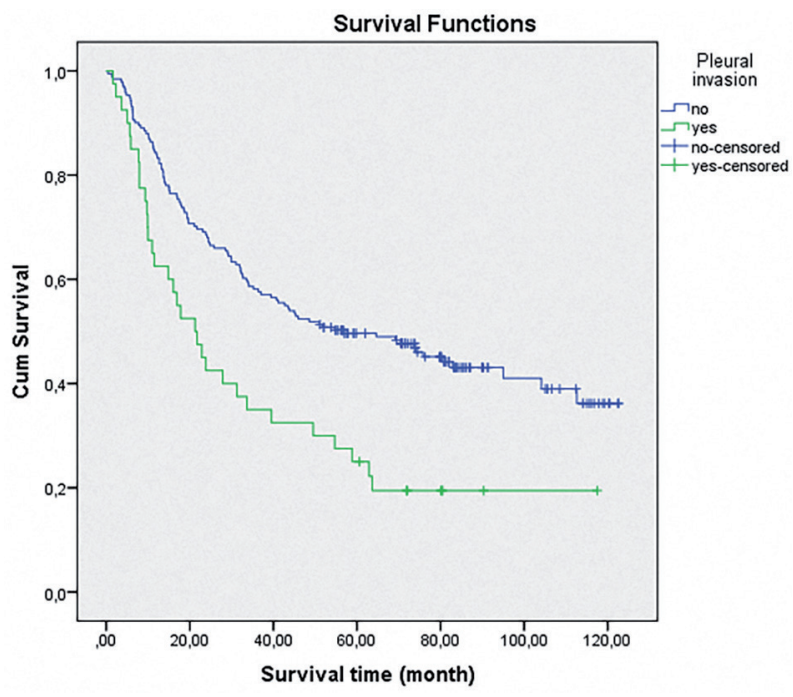

Figure 4. Survival distributions by pleural invasion

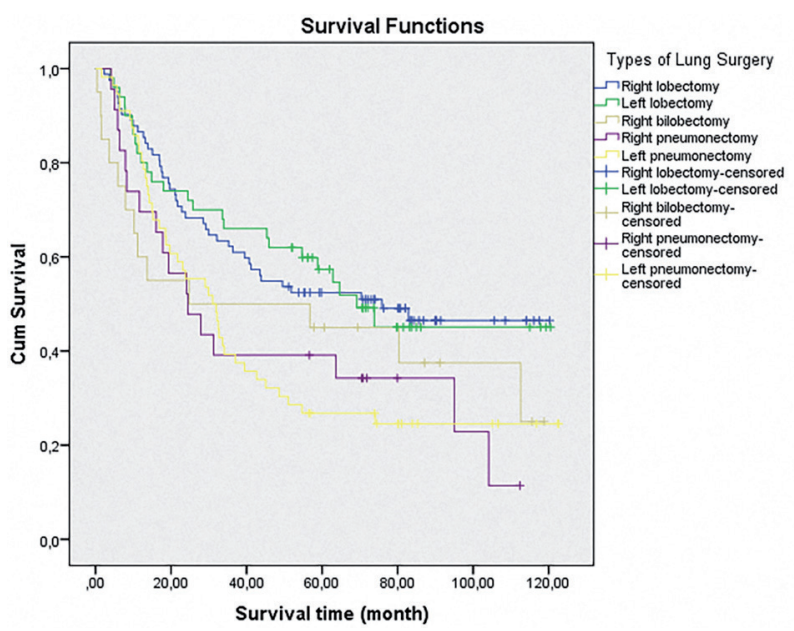

Figure 5. Survival distributions by surgical operation

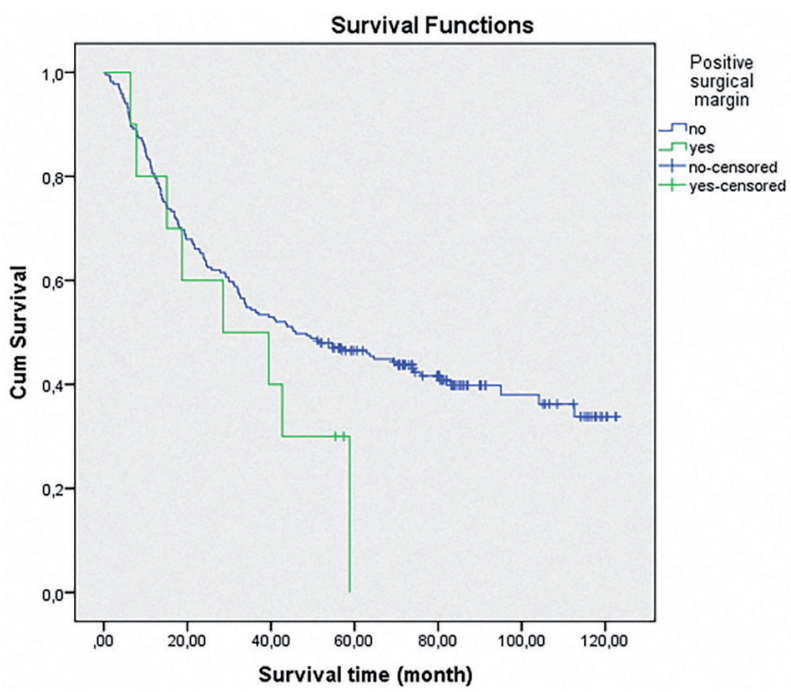

Figure 6. Survival distributions by resection margin invasion

\section{DISCUSSION}

We found that age, histopathology of adenocarcinoma, N2 stage, pleural invasion, pneumonectomy as a type of surgical operation and a resection margin invasion were independent negative prognostic factors associated with reduced survival in operated early- and local advanced-stage (IA-IIIA) NSCLC patients.

Age is one of the major determinant factors for lung cancer survival. Several studies have found age as independently predictive factors associated with shorter survival [8-10]. In these studies, elderly patients were found to have more comorbidities, worse performance and more advanced stages. In a study conducted by Radzikowska et al, the authors identified that age exceeding 50 years at diagnosis and nonsurgical treatment represented significant independent negative prognostic factors [11]. In the present study, the age factor was an independent predictor shortening survival and was determined to increase the risk of mortality by 1.042 point for each year.

Effect of gender on survival of operated NSCLC patients is evaluated in some studies. Many studies showed male sex as a poor prognostic factor. In a cohort study assessing 4.618 patients diagnosed with NSCLC, male sex was concluded to be an independent unfavorable prognostic indicator for survival [12]. Similarly Alexiou et al., found the survival to be significantly better for women with both squamous and non-squamous cell cancer sub types [13]. We did not found significant effect of gender on survival in our study. We considered that this finding might stem from the low total number of female patients in our study.

In a study, patients diagnosed with NSCLC, Kawaguchi et al. observed in multivariate analysis that good PS, was independent prognostic factors favorable for survival [14]. The present study found that patients with an ECOG performance score of ' 2 ' in Kaplan-Meier analysis had a significantly shorter survival time than those with scores of 0 and 1 . In addition, they were associated with a mortality risk that was close to the significant level in Cox regression analysis. There were no patients with ECOG PS over '2' score in our study. Generally patients with high score or poor performance are not operated on due to their functional inability. They usually have severe disease with co-morbidities, borderline or insufficient pulmonary reserves. Mortality rates may increase in these populations. 
T stage is another considerable factor for survival in operated NSCLC patients. A study assessing IAstage patients with a tumor diameter longer than $3 \mathrm{~cm}$ failed to identify any significant correlation between survival and tumor diameter [15]. Conversely, Harpole et al. performed a multi-variate analysis on 289 operated stage I patients and identified that a tumor diameter longer than $3 \mathrm{~cm}$ were independent predictors that shortened survival time [16]. The present study established an association between advancing $\mathrm{T}$ stage status and survival time upon comparing different $\mathrm{T}$ stages with each other. Although mean survival was 71.4 months for T1A cases, and only 44.6 months for $\mathrm{T} 3$ cases, this difference was not reflected significantly in the statistics due to the low number of patients in the given groups.

$\mathrm{N}$ stage is the main component of the pathological stage, shows lymph node involvement. The literature indicates that surgery would not provide any contribution to the survival of patients, unless they have lymph node metastasis of multiple stations (including Bulky N2) and T4, which could be removed in part [17]. In a study, it was found that for patients with completely resectable stage II NSCLC, number of involved N1 lymph nodes equal to or exceeding 3, were prognostic factors that were adverse for survival [18]. In the present study, we identified that $\mathrm{N}$ stage was an independent factor in shortening survival and predicting mortality. Mortality increased by 1.5 in N1 stage and 2.3 in N2 stage when compared to N0. Since advanced $\mathrm{N}$ stage indicates local spreading of the tumor; we thought that our findings are compatible with the literature.

In a study assessing patients in stages I and II, visceral pleural invasion (VPI) was established to be independently associated with reduced lung cancerspecific survival, upon checking the patients for tumor size and other confounders [19]. Kang et al. worked with T2 NSCLC patients that had been subject to resection, and determined visceral pleural invasion to be a factor of poor prognosis. Therefore, they recommended the close follow-up of patients with visceral pleural invasion specifically [20]. In the present study, the survival of patients with visceral pleural invasion was found to be significantly shorter than those without such invasion. As an independent prognostic factor, visceral pleural invasion was identified to increase the risk of mortality by 2.4 compared with the noninvasion group. Our results related to visceral pleural invasion were compatible with the literature.
Effect of micro vascular invasion (MVI) is another controversial issue. In a study conducted on lymphnode-negative early-stage patients that had been subject to resection, Naito et al. established that MVI was observed to be an independent negative prognostic factor and found as a stronger prognostic indicator than T size, according to the 2009 TNM staging system [21]. Likewise Ruffini et al. worked with patients diagnosed with NSCLC and operated in pT1-T2N0 stages and found that the presence of MVI was an independent negative prognostic factor [22]. However, Chandrachud et al. found in a survival analysis performed on operated NSCLC patients that tumor volume was the only factor affecting survival, the authors identified vascular invasion not to be a determining value in prognosis [23]. In the present study, patients representing vascular invasion had a shorter survival time than that of patients without invasion. However, this difference was not found to be significant.

Stage is the more important factor which is not only related to survival, but also used for planning resection, postoperative treatment and monitoring of patients. However due to $\mathrm{T}$ stage and $\mathrm{N}$ stage factors, which are already components of the tumor stage, were included in the multi-variety analysis, the simultaneous examination of the stage factor were not included in the regression analysis in the present study. Naruke et al. (2001) used the 1997 staging system in their study, where they found no significant difference in five-year survival times between stage IB and stage IIA, stage IIA and IIB, and stage IIIB and stage IV. In the postoperative stage, significant differences were identified in 5-year survival rates between all stage pairs other than stage IB and stage IIA [24]. In the present study univariate analysis, a significant correlation was determined between increased stage status and reduced survival. Every advancing stage after stage IA was associated with reduced survival time. The life expectancy was found to be 71.6 months for stage IA, but only 29.3 months for stage IIIA.

Surgical resection type is a considerable issue in operated NSCLC. In a study including operated NSCLC population comparing limited resection and others to lobectomy, no difference was identified between the resection groups in terms of survival [25]. Another study comparing pneumonectomy and lobectomy in early- or local advanced-stage cases again failed to establish any differences between these two groups in terms of long-term survival [26]. Martini et al. found five- and ten-year survival, to be significantly 
shorter among patients that had been subject to wedge resection or segmentectomy than those who had been subject to lobectomy [27]. In a study, Drukin et al. determined that the risk of mortality arising from the generalization of the disease in the first year decreased dramatically in a group of patients who had undergone extended and combined, pneumonectomy with N2, lobectomy in peripheral carcinoma with metastases of N2 level especially when the length of the tumor was above $5 \mathrm{~cm}$ [28]. The present study identified that left pneumonectomy increased the risk of mortality by 2.3 and right pneumonectomy by 1.5 when compared to lobectomy. Pneumonectomy was associated with dramatically reduced survival to a higher extent than that of lobectomy, with the shortest survival observed being with right pneumonectomy. The more extended resection may result in more postoperative complications and fall in pulmonary reserves. Moreover, many patients already have borderline pulmonary reserve with poor parenchyma. These factors and thoracotomy related some other factors [29] may contribute to worsening postoperative performance and increase vulnerability for mortal diseases.

Effect of resection margin invasion, remain controversial in operated NSCLC. In a study involving 1795 operated patients, resection margin invasion had not been found to be associated with survival [30]. Conversely, in another study, residual tumor in resection margin had been found to be associated with shorter survival time [31]. In the present study, life expectancy in those with surgical margin positivity was found to be 33.5 months, whereas this time was found to be 63.3 months for the margin-negative group. Cox regression analysis established that resection margin invasion increased the risk of mortality significantly (by 2.4) when compared to its absence.

In conclusion, the present study showed that advanced age, adenocarcinoma histological type, N2 lymph node metastasis, pneumonectomy procedure and the resection margin invasion were associated with a significantly increased risk of mortality in operated stage IA-IIIA NSCLC patients. Therefore, it is considered that during planning of surgical operation and long-term postoperative follow-up of these patients should be undertaken in a more frequent and attentive manner.

Declaration of Conflicting Interests: The authors declare that they have no conflict of interest.

Financial Disclosure: No financial support was received.

\section{REFERENCES}

1. Scott WJ, Howington J, Feigenberg S, et al. Treatment of non-small cell lung cancer stage I and stage II: ACCP evidence-based clinical practice guidelines ( $2^{\text {nd }}$ edition). Chest. 2007; 132:234s-42s.

2. Birim O, Zuydendorp HM, Maat AP, et al. Lung resection for non-small-cell lung cancer in patients older than 70: mortality, morbidity, and late survival compared with the general population. Ann Thorac Surg. 2003;76:1796-801.

3. Thorsteinsson H, Alexandersson A, Oskarsdottir GN, et al. Resection rate and outcome of pulmonary resections for non-small-cell lung cancer: a nationwide study from Iceland. J Thorac Oncol. 2012;7:1164-9.

4. Oskarsdottir GN, Skuladottir R, Isaksson HJ, et al. [Factors predictive of survival after lobectomy for non-small cell lung cancer in Iceland during 1999-2008]. Laeknabladid. 2010;96:251-7.

5. Yu DP, Bai LQ, Xu SF, et al. [Impact of TNM staging and treatment mode on the prognosis of non-small cell lung cancer]. Zhonghua zhong liu za zhi [Chinese J Oncol]. 2009;31:465-8.

6. Oken MM, Creech RH, Tormey DC, et al. Toxicity and response criteria of the Eastern Cooperative Oncology Group. Am J Clin Oncol. 1982;5:649-6.

7. Goldstraw P. The $7^{\text {th }}$ Edition of TNM in Lung Cancer: what now? J Thoracic Surg Oncol. 2009;4:671-3.

8. Greenlee RT, Murray T, Bolden S, Wingo PA. Cancer statistics, 2000. CA Cancer J Clin. 2000;50:7-33.

9. Liu M, Cai X, Yu W, et al. Clinical significance of age at diagnosis among young non-small cell lung cancer patients under 40 years old: a population-based study. Oncotarget. 2015;6:44963-70

10. Radzikowska E, Glaz P, Roszkowski K. Lung cancer in women: age, smoking, histology, performance status, stage, initial treatment and survival. Population-based study of 20 561 cases. Ann Oncol. 2002;13:1087-93.

11. Radzikowska E, Głaz P, Roszkowski K. Lung cancer in women: age, smoking, histology, performance status, stage, initial treatment and survival. Population-based study of 20 561 cases. Ann Oncol. 2002;13:1087-93.

12. Visbal AL, Williams BA, Nichols FC, et al. Gender differences in non-small-cell lung cancer survival: an analysis of 4,618 patients diagnosed between 1997 and 2002. Ann Thorac Surg. 2004;78:209-15.

13. Alexiou C, Onyeaka CV, Beggs D, et al. Do women live longer following lung resection for carcinoma? Eur J Cardiothorac Surg. 2002;21:319-25.

14. Kawaguchi T, Takada M, Kubo A, et al. Performance status and smoking status are independent favorable prognostic factors for survival in non-small cell lung cancer: a comprehensive analysis of 26,957 patients with NSCLC. J Thorac Oncol. 2010;5:620-30.

15. Patz EF, Rossi S, Harpole DH, et al. Correlation of tumor size and survival in patients with stage IA non-small cell lung cancer. Chest. 2000;117:1568-71. 
16. Harpole DH, Herndon JE, Young WG, et al. Stage I nonsmall cell lung cancer. A multivariate analysis of treatment methods and patterns of recurrence. Cancer. 1995;76:78796.

17. Ma Q, Liu D, Guo Y, et al. Surgical therapeutic strategy for non-small cell lung cancer with mediastinal lymph node metastasis (N2). Zhongguo Fei Ai Za Zhi. 2010;13:342-8.

18. Dai Y, Su XD, Long H, et al. Survival analysis of 220 patients with completely resected stage-II non-small cell lung cancer. Chinese J Cancer. 2010;29:538-44.

19. Lakha S, Gomez JE, Flores RM, Wisnivesky JP. Prognostic significance of visceral pleural involvement in early-stage lung cancer. Chest. 2014;146:1619-26.

20. Kang JH, Kim KD, Chung KY. Prognostic value of visceral pleura invasion in non-small cell lung cancer. Eur J Cardiothorac Surg. 2003;23:865-9.

21. Naito Y, Goto K, Nagai K, et al. Vascular invasion is a strong prognostic factor after complete resection of node-negative non-small cell lung cancer. Chest. 2010;138:1411-7.

22. Ruffini E, Asioli S, Filosso PL, et al. Significance of the presence of microscopic vascular invasion after complete resection of Stage I-II pT1-T2N0 non-small cell lung cancer and its relation with T-Size categories: did the 2009 7th edition of the TNM staging system miss something? J Thorac Oncol. 2011;6:319-26.

23. Chandrachud L, Pendleton N, Chisholm D, et al. Relationship between vascularity, age and survival in non-small-cell lung cancer. Brit J Cancer. 1997;76:1367-70.
24. Naruke T, Tsuchiya R, Kondo H, Asamura H. Prognosis and survival after resection for bronchogenic carcinoma based on the 1997 TNM-staging classification: the Japanese experience. Ann Thorac Surg. 2001;71:1759-64.

25. Kates M, Swanson S, Wisnivesky JP. Survival following lobectomy and limited resection for the treatment of stage I non-small cell lung cancer $<=1 \mathrm{~cm}$ in size: a review of SEER data. Chest. 2011;139:491-6.

26. Kim DJ, Lee JG, Lee CY, et al. Long-term survival following pneumonectomy for non-small cell lung cancer: clinical implications for follow-up care. Chest. 2007;132:178-84.

27. Martini N, Bains MS, Burt ME, et al. Incidence of local recurrence and second primary tumors in resected stage I lung cancer. J Thorac Cardiovasc Surg. 1995;109:120-9.

28. Drukin E, Preis VG, Mikhnin AE, et al. [Analysis of one-year mortality of radically operated patients over 70 years with nonsmall cell lung cancer]. Voprosy Onkologii. 2014;60:88-93.

29. Ng CS, Lee TW, Wan S, et al. Thoracotomy is associated with significantly more profound suppression in lymphocytes and natural killer cells than video-assisted thoracic surgery following major lung resections for cancer. J Invest Surg. 2005;18:81-8.

30. Poullis M, McShane J, Shaw M, et al. Bronchial resection margin and long-term survival in non-small-cell lung cancer. Asian Cardiovasc Thorac Ann. 2012;20:432-8.

31. Yue D, Wang C. [Surgical resection standard and prognostic analysis of non-small cell lung cancer]. Zhonghua Zhong Liu Za Zhi. 2014;36:532-5. 